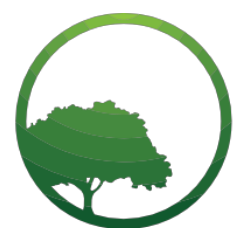

Business \& Social Science IJRBS

\section{Research in Business and Social Science}

IJRBS Vol 7 No 4, ISSN: 2147-4478

Contents available at www.ssbfnet.com/ojs

\title{
Good Governance in Private University in Medan City
}

\section{Maya Sari}

Lecturer of Economic Faculty, University Of Muhammadiyah Sumatera Utara

\section{Muhammad Qorib}

Lecturer of Economic Faculty, University Of Muhammadiyah Sumatera Utara

\section{Seprida Hanum Harahap}

Lecturer of Economic Faculty, University Of Muhammadiyah Sumatera Utara

\section{Jufrizen}

Lecturer of Economic Faculty, University Of Muhammadiyah Sumatera Utara

\begin{abstract}
The purpose of this study was to create transparency, accountability, participation, effectiveness and consistency in private universities in the city of Medan. To obtain the data needed in this study, researchers used data collection techniques by means of surveys. Researchers do this by distributing questionnaires to lecturers and / or employees at Private Universities in Medan City. The results of the study showed that Good Governance has been running well at Private Universities in Medan City, and most respondents stated their agreement that aspects of transparency, participation, accountability, and effectiveness have gone well. This was supported by the results of research that good governance at private universities in Medan city $87 \%$ have applied the aspect of transparency, $90 \%$ have applied the aspect of Participation, $51 \%$ have implemented accountability, and $87 \%$ have applied the aspect of effectiveness.
\end{abstract}

Key words: Good Governance, Private University

JEL classification: G32, G34, M14,

Submitted: 04.09.2018 - Accepted: 11.11.2018

\section{Introduction}

The university is currently facing market pressure (market pressure) which demands that it has to change management. Higher education is faced with several challenges, namely improving quality, relevance, equity, efficiency and governance (Nizam, 2006). The university should be able to ensure that good governance can 
be applied to all levels of the university's institutions. To achieve good university governance, every university is required to meet the National Higher Education Standards (SNPT) in accordance with the Minister of Education and Culture of Republic Indonesia concerning National Standards for Higher Education (SNPT). National Standard for Higher Education (SNPT), which is a standard unit that includes national education standards, coupled with research standards, and community service standards. SNPT aims to ensure that higher education organized by the university in accordance with the minimum criteria of the education, research and community service system, in all the jurisdictions of Republic Indonesia. SNPT must be fulfilled by every university. SNPT must be the basis for granting university establishment permits and opening study programs and internal quality assurance systems. SNPT must be the basis for determining criteria for an external quality assurance system through accreditation. The scope of SNPT consists national education standards, research standards and community service standards. With the implementation of SNPT by universities especially private universities, PTS good governance can be realized.

There are six things that must be considered in managing a good university based on the standards of University accreditation forms, namely: Civil Service / Leadership, Students and Graduates, Human Resources, Curriculum and Teaching, Finance and infrastructure, as well as Research and dedication. Private universities as part of higher education institutions in Indonesia are also faced with the same challenges. This is what simultaneously encourages a paradigm shift developed in national education that relies on three main things, namely independence, accountability, and assurance. Looking at the explanation above, the basic things that are important to be realized and become a challenge for private universities are how the university embodies Good governance. The aspects or parameters of measurement both good governance and good corporate governance vary widely, including: (1) transparency; (2) participation; (3) accountability; (4) responsibility; (5) independency; (6) fairness; (7) rule of law; and (8) efficiency and effectiveness. However, in this study, measurement parameters were limited to aspects of (1) transparency; (2) participation; (3) responsibility; (4) rule of law; and (5) efficiency and effectiveness.

This research is based on a desire and effort to improve the quality of universities, especially private universities, the demands of the community who are eager for the availability of high-quality private universities. Researchers see that one that can be taken to make a strong, high-quality, and sustainable sustainable private university is to improve the quality of good governance and benefit private universities in Medan. The application of good governance is to make a strong, high-quality, and sustainable private university, through improving the quality of good governance so that it can improve the quality of private universities in the city of Medan.

\section{Literature Review}

\section{College Management}

Referring to Government Regulation Number 4 of 2014 concerning Implementation of Higher Education and Higher Education Management, article 1, what is meant by higher education is the level of education after secondary education which includes (1) diploma program; (2) undergraduate programs; (3) master program; (4) doctoral program; professional program; (5) and specialist programs. Which all of these programs are organized by universities. Meanwhile, universities are education units that carry out higher education. Higher education in the form of (1) university; (2) institute; (3) high school; (4) polytechnics; (5) academy; and (6) community academics. Furthermore, it was stated that the arrangement of universities included: (1) autonomy of universities; (2) the pattern of university management; (3) university governance; and (4) public accountability. Referring to Government Regulation Number 4 of 2014, universities have the authority related to (1) the autonomy of higher education; (2) the pattern of university management; (3) university governance; and (4) public accountability. Meanwhile, referring to the views of Indrajit \& Djokopranoto (2006), there are 5 (five) dimensions that are inherent in universities, namely: Scientific dimensions (science and technology), dimensions of education, social dimensions, corporate dimensions, ethical dimensions. In the context of the corporate dimension, universities provide services to the community in the form of higher education of learning and teaching and research processes, which are taught and studied are science. So the college business is science. Another similarity between universities and corporations are that both have core business and supporting business. Indrajit \& Djokopranoto (2006) gave the term front office process - the 
field of academic services or the learning process and pursuit - and back office process - for the field of academic and non-academic administration services.

\section{a. Academic services (front-office-services).}

The front-office services are referred to as core products and services as the main products offered to customers. In the context of higher education in Indonesia, it is called the Tri Dharma Perguruan Tinggi, which covers aspects of education, research and community service.

b. Field of academic and non-academic administration services (back-office-services).

The back-office-services sector is a front-office-services support unit, such as: student administration services, financial and accounting management, human resource management, academic administration, campus infrastructure management, and so on. The extent or absence and complexity of the BackOffice section is very much determined by the size of the high school concerned. Higher education stakeholders are various parties that have links and interests both directly and indirectly at a university. Tampubolon (2001) mentions stakeholders are customers. there are three categories of college customers or stakeholders, namely:Primary customers, namely students because they have direct influence in living and utilizing university products and participating in the production process;Secondary customers, including college management (university leaders, faculty staff and administrative staff), parents, community, government, donor and environmental organizations;Tertiary customers, namely parties who have interests with a university, such as: the world of work, further education institutions and the environment.

When, Cortese (2003) categorizes tertiary stakeholders into two, namely:

1. Internal stakeholders - faculty, operational staff, students; and

2. External stakeholders - parents, alumni, local and regional communities, donors and the government.

Furthermore, Tampubolon (2001) states that high-level college customers are influenced by college products and the processes occur in the production and presentation of college products. The term affected implies (1) it is directly affected by living and utilizing the product and participating in its production and presentation; (2) indirectly affected by the product and its production and presentation; and (3) 0 there is a change in the affected self.

\section{Good Governance}

The World Bank provides a definition of the state of power is used in managing the economy and social resources for development of society. UNDP provides the definition of the authority of political, economic and administrative authority to manage a nation's affair at all levels. According to this definition, three legs of good governance are: economic, political and administrative. Economic governance encompasses decisionmaking processes that facilitate domestic economic activity and interaction among economic organizers. UNDP provides a definition of good governance as a synergistic and constructive relationship between the state, the private sector and society. UNDP provides characteristics of good governance, namely: Participation, Rule of Law, Transparency, Responsiveness, Consensus Orientation, Equity, Effectiveness and Efficiency, Accountability, and Strategic Vision (LAN and BPKP, 2000). The concept of good governance refers to how good corporate governance is. Good governance at universities is needed to encourage the creation of efficiency, transparency and consistent with the legislation. The application of good governance needs to be supported by three interconnected pillars, namely the state and its tools as regulators, the business world (including universities) as market participants, and the community as stakeholders and users of business products / services. In 1999, the National Committee on Good Governance Policy (KNKCG) issued the first Regulation on Good Governance (GCG) and was perfected in 2001. Good governance principles, namely: transparency (transparency), independence, accountability, responsibility, equality and fairness.

\section{Transparency (Transparency)}

Basic principles: to maintain objectivity in running a business, companies must provide material and relevant information in ways that are easily accessible and understood by stakeholders. The company must take the 
initiative to disclose not only the problems required by the legislation, but also matters that are important for decision making by shareholders, creditors and other stakeholders. In the Implementation Principles, it is stated that:

a. The company must provide timely, adequate, clear, accurate and comparable information that is easily accessible to stakeholders in accordance with their rights.

b. Information that must be disclosed includes, but is not limited to, the vision, mission, business objectives and corporate strategy, financial condition, arrangement and compensation of management, controlling shareholders, share ownership

c. The principle of openness adopted by the company does not reduce the obligation to fulfill the company's confidentiality requirements in accordance with the laws and regulations, position secrets, and personal rights.

d. Company policies must be written and proportionally communicated to stakeholders.

\section{Accountability}

Basic principles: companies (including universities) must be able to account for their performance transparently and fairly. In the Principal Guidelines, the implementation is stated:

a. The company must specify the details of the duties and responsibilities of each company organ and all employees clearly and in line with the company's vision, mission, business objectives and strategies.

b. The company must ensure that all the company's organs and all employees have competencies in accordance with their duties, responsibilities, and roles in the implementation of good good governance.

c. The company must ensure an effective internal control system in managing the company.

d. Companies must have a performance measure for all levels of the company that is consistent with the company's values, the main goals and strategies of the company, and has a reward and punishment system.

e. In carrying out its duties and responsibilities, each company organ and all employees must adhere to agreed business ethics and code of conduct.

\section{Responsibility}

Basic principles: companies (including universities) must comply with the laws and regulations and carry out their responsibilities to society and the environment so that they can maintain long-term business continuity and get recognition as good corporate citizens. In the Principal Guidelines, the implementation is stated:

a. Company organs must adhere to the precautionary principle and ensure compliance with laws and regulations, by-laws and by-laws.

b. The company must carry out social responsibility by caring for the community and environmental sustainability, especially around the company by making adequate planning and implementation.

\section{Independence (Independency)}

Basic principle: To expedite the implementation of GCG principles, companies must be managed independently so that each organ of the company does not dominate each other and cannot be intervened by other parties. In the Principal Guidelines, the implementation is stated:

a. Each organ of the company must avoid domination by any party, not affected by certain interests, free from conflicts of interest and from any influence or pressure, so that decision making can be carried out objectively.

b. Each organ of the company must carry out its functions and duties in accordance with the articles of association and legislation, not dominate each other and or throw responsibilities between one another so as to realize an effective internal control system. 


\section{Equality and Fairness}

Basic principle: in carrying out its activities, the company must always pay attention to the interests of shareholders and other stakeholders based on the principle of equality and fairness. In the Principal Guidelines, the implementation is stated:

a. Companies must provide opportunities for stakeholders to provide input and express opinions for the interests of the company and open access to information in accordance with the principles of transparency in the scope of their respective positions.

b. The company must provide equal and reasonable treatment to stakeholders in accordance with the benefits and contributions given to the company.

c. Companies must provide equal opportunities in employee recruitment, careers and carry out their duties professionally regardless of ethnicity, religion, race, gender, and physical condition.

\section{Application of the Principles of Good Governance in Universities}

Good governance principles, namely: transparency (transparency), independence (accountability), accountability, responsibility, equality and fairness. These principles are needed at the university to achieve sustainable performance while paying attention to stakeholders. Should the university should be fostered awareness that the demand for good governance is not only an obligation, but rather a necessity. Along with the increasingly fierce competition situation, universities must continue to strive to realize good university governance as a system that is inherent to the dynamics of the university. The concept of Good Corporate Governance (GCG) is a breakdown of the GG concept. GCG is one of the concepts that are becoming a strategic and mainstream issue in good corporate governance. Referring to the view of Satryo Brodjonegoro that good universities must be willing to adopt corporate management. So, the concept of GCG is also appropriate and appropriate to be applied in universities. GCG itself is a concept of how good corporate governance is to be able to survive and be competitive.

GCG in universities is needed in order to encourage behavior in managing higher education institutions that are efficient, effective, transparent and consistent with the laws and regulations. By referring to the meaning of GCG, the GUG can be interpreted as the structure, system, and process used by higher education institutions as an effort to continuously value the product or process.

Referring to the United Nations Development Program (UNDP) as quoted by Sutiono (2004) in Djanali (2005) states that indicators of good governance success, if (1) includes all; (2) transparent and responsible; (3) effective and fair; (4) guaranteeing the rule of law; (5) ensuring that political, social and economic priorities are based on community consensus; (6) pay attention to the weakest in decision making. Referring to Ali Hanapiah Muhi (none), stating that the principle of GUG, namely transparency, independence, accountability, responsibility, equality, and fairness is needed in universities to achieve sustainable performance while still paying attention to stakeholders. Furthermore, the aim of the GCG policy in universities is so that the parties who play a role in managing higher education understand and carry out the functions and roles according to authority and responsibility. Parties that play a role include the Board of Trustees, Board of Trustees, Senate, Chancellor and Vice Chancellors, committees (if any), Heads of bureaus, Deans and dean assistants, structural officials, lecturers, leaders and employees.

Muhi gives an overview of the application of the GUG principle to governance in universities:

a. Transparency. Higher education as an industry, is responsible for the obligation of information disclosure and provides information to stakeholders, so that the position and management of corporations (universities) can reflect the real conditions and expectations of higher education in the future. In this context, Muhi outlines in (1) the transparency of the decision-making process; (2) transparency to business partners; and (3) transparency of employee performance appraisal; b. Independence. In connection with the aspects of independence, the chancellor, trustee, and senate have independent opinions in every decision taken. In addition, it is also possible to obtain advice from independent consultants and legal consultants to support the chancellor's business; c. Accountability. To uphold accountability, it is necessary to clarify the function, implementation and accountability of all organs in the organization, so that the management of the institution is carried 
out effectively. In this context, more attention is related to accountability aspects in the delivery of financial statements, and aspects of accountability in human resources;

d. Accountability. The university must always prioritize conformity in the management of higher education according to the prevailing laws and regulations and the principles of sound and quality institutions. Each part / unit has clear duties and functions, with the allocation of each responsibility clearly stated in the higher education policy;

e. Equality and Fairness. To meet the aspects of equality and fairness in the delivery of information, universities can apply equal treatment to the entire academic community. Both fairness in terms of relations with the academic community, fairness of procurement of goods / services, fairness of information, and other fairness.

In the measurement or assessment of GUG, this research refers to Dadang Solihin (2007), namely there are four aspects that need to be measured in GG, namely accountability, supermasi law, transparency, and participation by adjusting the context of university management

\section{Research and Methodology}

This research approach was descriptive quantitative research. In the context of this study, researchers intend to describe the phenomenon or state the application of the principles of Good Governance (GG) to private universities in the city of Medan. This research includes development research (development research) that produces a model of developing good governance as an effort to improve the quality of private universities so as to make quality private universities. This research was conducted at a private university in Medan City. The population in this study were lecturers and employees of private universities in the city of Medan. The sampling technique is to use 5 times the indicator, namely 170 respondents from private universities in Medan. In this study, the data used are qualitative and qualitative data. To obtain the data needed in this study, researchers used data collection techniques by means of surveys. Which survey is a research by taking a sample from one population and using a questionnaire as a primary data collection tool. In order to obtain data through a survey approach, researchers conducted a method of distributing questionnaires to lecturers and / or employees in the private university of Medan. Data collection techniques used in this study include observation of participation / observation, study of documentation, interviews with relevant parties and giving questionnaires to related parties. The number of returned questionnaires was 158 respondents.

\section{Result and Discussion}

\section{Transparency aspect}

The transparency aspect is illustrated by three indicators which are clarified again through the 9 statement items in this research questionnaire, including (1) transparency in the delivery of information; (2) Media for information delivery (Website), manuals, SOPs, notice boards, printed \& electronic goods; (3) Effectiveness of information delivery. Based on the results of the study, the level of transparency in the management of tertiary institutions is above the average of $86 \%$. This figure shows that most respondents stated that private universities were transparent in the field of information delivery, but when answering related to transparent questions in the field of financial management, respondents' answers varied greatly. Most respondents said they were not or less, and very few said they were transparent, let alone transparent. Therefore, it can be concluded that private universities in the city of Medan are actually transparent and that there is an easy access to information in the field of information that is not directly related to financial management. But on the contrary, it is not or less transparent in a field that is directly related to the financial management of private universities. Private universities as one of the education units of higher education providers function to provide fair and quality services to students by prioritizing the principle of non-profit and can manage funds independently to advance education services by upholding the principle of transparency. Private universities, should be expected to be a model for managing universities with good governance. One of them is promoting transparency in the management of its bureaucracy. The community must be able to see how universities manage all the assets and human resources that are within the scope of their institutions. So that, people can find out and provide input to realize ideal universities. Thus, the concept of Good Governance in 
universities or Good University Governance is needed in order to encourage behavior in managing higher education institutions that are efficient, effective, transparent and consistent with the laws and regulations.

\section{a. Aspect of Participation}

One of the principles in Good Governance is participation. The intended participation was community participation in the management of institutions or government. Participation aspects are explained by 4 indicators which are then conveyed in 5 statements, including (1) key stakeholders involved in decision making / policy; (2) Stakeholders are involved in the planning process; (3) Stakeholders are involved in policy oversight; (4) Stakeholders are involved in policy formulation. In this study, the aspect of participation that asked was participation related to stakeholder involvement in terms of decision makers or policies, participation in the planning process, participation in policy oversight, and participation in policy formulation. Based on the results of the study, the level of participation or involvement of stakeholders in the management of higher education was above the average of $88 \%$. This figure shows the degree of soldering participation. This involvement can be in the form of awareness of the solder itself or indeed be involved by the management of the university. But based on the results of observations, this soldier participation was more involved rather than involving voluntarily. This means that internal stakeholders will participate in decision / policy makers, the process of planning, supervision and policy formulation, if the stakeholders are deliberately involved by the management of private universities. Thus, the management of private universities, in terms of participation from the campus community in particular has been relatively high. Although, this involvement must have binding regulations. Indeed, not all private University stakeholders are directly involved, most of the internal stakeholders involved in policy formulation, policy implementation, and policy supervision are key internal stakeholders, such as the chancellor, vice chancellor, dean, vice dean, head of agency, head of the head, bureau, head of other UPT.

\section{b. Accountability aspects}

Accountability is one of the important principles in Good Governance. In addition, it is a principle developed and implemented by public institutions. The issue of accountability is also emphasized for the delivery of higher education and the management of higher education, as stated in Government Regulation Number 4 of 2014, which states that in higher education settings one must be accountable to public or public accountability. This level of accountability is measured by various parameters, among others, the aspect of accountability is described by 5 indicators, including (1) the existence of a Standard Operating Procedure (SOP) in the implementation of higher education; (2) The mechanism of accountability for the administration of higher education; (3) The existence of an annual report; (4) Report on accountability of activities; (5) The existence of a control system for the administration of higher education. Each of these measurement parameters, the data from the research analysis shows that on average $51 \%$ stated their agreement to the accountability. This means that the level of accountability of private university management is adequate even though there is still something that must be improved continuously. This accountability is strongly supported by the level of availability and compliance with the applicable laws and regulations. Based on the results of qualitative data analysis, most respondents said that they had led to accountability even though it was not yet maximal. Thus, it can be concluded that public accountability in the management of private universities was generally good, but needs to be improved continuously and needs the support of all parties.

\section{Aspect of Effectiveness}

Based on the results of research conducted in several private universities in Medan, the effectiveness aspect was measured by several parameters, including (1) the existence of a Standard Operating Procedure (SOP) in the implementation of higher education; (2) The mechanism of accountability for the administration of higher education; (3) The existence of an annual report; (4) Report on accountability of activities; (5) The existence of a university controlling the implementation of higher education. Based on the results of the study, the level of effectiveness in the management of higher education was an average of $86 \%$. Private universities in Medan City in the context of the effectiveness of higher education implementation have been effective in organizing higher education and managing tertiary institutions. This was measured by the clarity parameters of the vision, mission, and purpose statements; clarity of achievement strategies; clarity of the achievement 
program; and the balance between the program and its budget. From the analysis of research data, most of them agreed that private universities in Medan City had a clear vision, mission, objectives, programs and goals to be achieved in the future; clarity of strategies for achieving the vision, goals, programs and objectives formulated; confidence between plans and results; and balance between resource users and program implementation.

\section{Conclusion}

Based on the exposure and discussion as above, it can be summarized that in fact Good Governance has been applied to private universities in Medan. Based on the results of statistical analysis, most respondents stated their agreement that aspects of transparency, participation, accountability, and effectiveness were good. In detail, namely; in the aspect of transparency, $87 \%$ of respondents stated their agreement on the implementation of good governance at private universities in Medan, $90 \%$ of respondents stated their agreement in the implementation of good governance at private universities in the city of Medan. Implementation of good governance at private universities in the city of Medan, on the aspect of effectiveness as much as $87 \%$ of respondents stated their agreement in the implementation of good governance at private universities in the city of Medan.

\section{References}

Aristo, A.D., (2005). Good University Governance. http://aristodiga.blogspot.com/ 2005/08 / gooduniversity-governance.html

Ali, A. (2007). Building Good Governance at Universities in Indonesia

Daniri, A. (2004). Consistent with Good Good governance. HTTP: //www.Sinar hope.co.id/ceo/2004/0119/ceo2.html

Djajendra, with Good Good Governance Culture. http://bppn-gcg.blogspot.com/

Esha, Muhammad In-et al. (2006). 2 Years of UIN Malang: University Academic Reorientation. Malang: UIN-Malang Press.

Kunami, A. (2007). Implementation of Good Good governance. http://djajendra.blog.co.uk/2007/11/04/bawatan_dengan_kultur_good_corporate_gov 3242469

LAN and BPKP (2000). Accountability and Good Governance. State Administration Agency. Jakarta.

Mok, Ka Ho and Yat Wai Lo. (2007). The Impact of Neo-Liberalism on Chinese Higher Education. Journal of Critical Policy Education Studies Vol. 5 No. 1 (May).

Nizam, (2006). Indonesia. in UNESCO, Higher Education in Southeast Asia, Bangkok: UNESCO.

Prewitt, Kenneth. (2004). Higher Education, Society, and Government: Dynamic Change. Journal of Higher Education in Africa. Vol. 2 No. 1. PP. 35-56.

Aljifri, K. and Moustafa, M. (2007). Impact of Good Governance Mechanisms on UAE Company Performance: Empirical Analysis, College of Business and Economics, University of UAE, Journal of Economic \& Administrative Sciences Vol. 23, No. 2, December 2007 (71-93).

Denis, D. K., \& McConnell, J. J. (2003). International Good Governance. Journal of Financial and Qualitative Analysis, 38; 1-36.

Denis, D. K. (2001). Twenty-five years of good governance research ... and growing. Review of Financial Economics, 10; 191-212 27

FCGI, (2000). Good governance. Forum for good governance in Indonesia. Jakarta.

Herwidayatmo, (2000). Implementation of Good Governance for Public Companies in Indonesia. Business Magazine, October, No.10 / Th.XXIX

KNKG, (2009). General Guidelines for Good Good Governance in Indonesia. Jakarta: National Committee. Maksum, Azhar (2005). Information on Good Good Governance in Indonesia. Speech of Inauguration of Permanent Professors in the Field of Management Accounting in the Faculty of Economics, University of North Sumatra.

OECD (2004). Principles of Good Governance. Paris, France, OECD Publication Services.

Bank Indonesia Regulation Number 8/4 / PBI / 2006 concerning Implementation of Good Good Governance for Commercial Banks, LNRI in 2006 Number 6 DPNP. 
Maya Sari et al / International Journal of Research in Business and Social Science,

Vol 7 No 4, 2018 ISSN: 2147-4486

Syakroza, Akhmad. (2009).Good governance: History and Development, Theory, Models and Government Systems and Their Applications to BUMN Companies., Speeches for Inauguration of Permanent Professors of the Faculty of Economics, University of Indonesia, Jakarta: Institute of Publishers FE.

Wulandari, Etty Retno. (2007), Good Governance: Concepts, Principles, and Practices. Jakarta: Board of Commissioners and Director of Indonesia 